\title{
FEATURE Polders, dikes, canals, rice, and aquaculture in the Mekong Delta
}

\author{
Kenneth R. Olson and Lois Wright Morton
}

A

quarter of a century ago, the Mekong Delta of southern Vietnam and southeast Cambodia was a vast swamp of freshwater and saltwater marshes, with half the region under water for many months of the year (Taylor 2014). The warm, moist prevailing winds of the southwest monsoon bring continuous rain May through October, high rates of runoff, and extensive flooding throughout the delta. Much of the low-lying alluvial plain where the Mekong River and its distributary, the Bassac River, flow south into the South China Sea is barely 2 to $3 \mathrm{~m} \mathrm{(6} \mathrm{to} 10 \mathrm{ft}$ ) above sea level (figure 1). Seawater incursions from tides and wave action bring salt water into coastal areas and upriver lands adjacent to river distributaries that outlet into the Gulf of Thailand and the South China Sea.

Colonial geographers and surveyors of the 1800s reported the Mekong Delta as an inhospitable, underpopulated land with salty-acidic soils, a scarcity of fresh water during the dry season, and indigenous people infected by malaria (Taylor 2014). The Dutch dike strategy of dikes and polders initiated by colonial governments in the 1930s pumped fresh water into rice (Oryza sativa L.) fields and was intended to protect the soil from saltwater incursions and maintain water levels during the dry season (Biggs 2011). However, it was not until the 1980s and 1990s that an extensive system of irrigation canals channeled fresh water from the Mekong and Bassac rivers into lands that were salty and acidic and enabled intensive agricultural production.

Today this densely populated region of over 15 million people and 50,000 $\mathrm{km}^{2}\left(19,300 \mathrm{mi}^{2}\right)$ of fertile soil is a leading agricultural exporter of rice (figure 2),

Kenneth R. Olson is professor emeritus of soil science in the Department of Natural Resources and Environmental Sciences, College of Agricultural, Consumer, and Environmental Sciences, University of Illinois, Urbana, Illinois, and Lois Wright Morton is professor emeritus of sociology in the Department of Sociology, College of Agriculture and Life Sciences, lowa State University, Ames, lowa.

\section{Figure 1}

Map of the Mekong Delta in Vietnam and Cambodia. A narrow trough of the ancient South China Sea covered land north of Phnom Penh creating the delta lowlands. Map by Mic Greenberg.

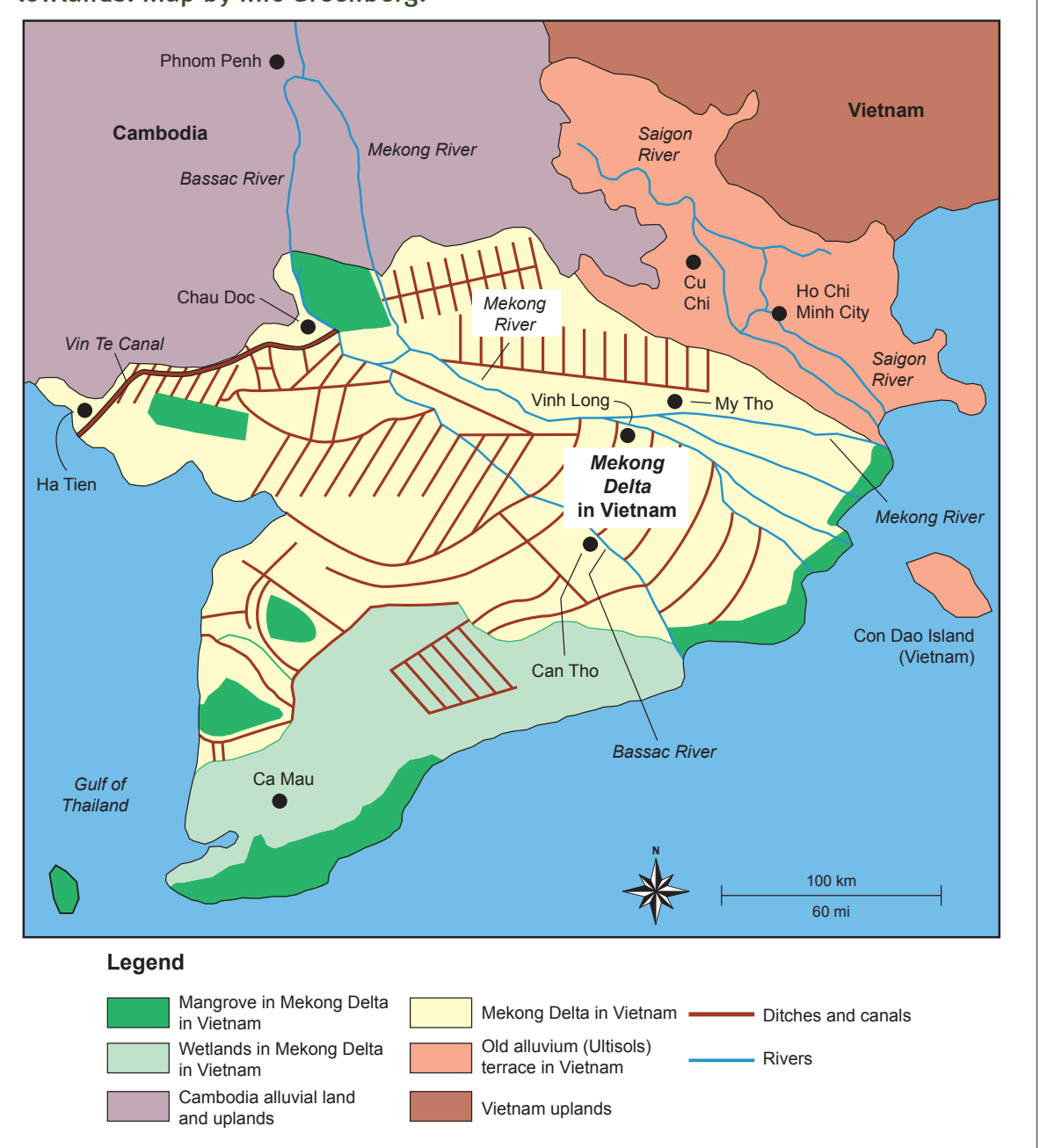

shrimp, and catfish. Canals, dikes, polders, and new varieties of rice have transformed the landscape into high-yielding rice paddies and shrimp ponds. Although most farmers are small-scale producers and fishers (Morton and Olson 2018), commercial aquaculture is significant in the Vietnam Delta, with a small percentage of households contributing a sizable portion of total production (Hortle 2007). The draining of swamps and marshes, expansion of canal networks, and land reclamation projects have reconfigured historic hydrological, ecological, agricultural, and social patterns of the Mekong Delta. Much like
American river floodplains, swamps, and forested bottomlands that were drained under the US Swamp Land Acts of 1849 to 1860 (Olson and Morton 2016), vast stretches of the Mekong Delta wetland wildness were drained to control flooding, encourage settlement and commerce, and expand land cultivation.

These engineering efforts are an agricultural and economic success story that has helped develop and modernize Vietnam and Cambodia. However, the canals and waterways that support aquaculture and dike and polder farming systems have displaced the delta wetlands 


\section{Figure 2}

Barge-like boats motor up and down the Mekong River carrying rice to processing mills for husk removal and bagging for export.

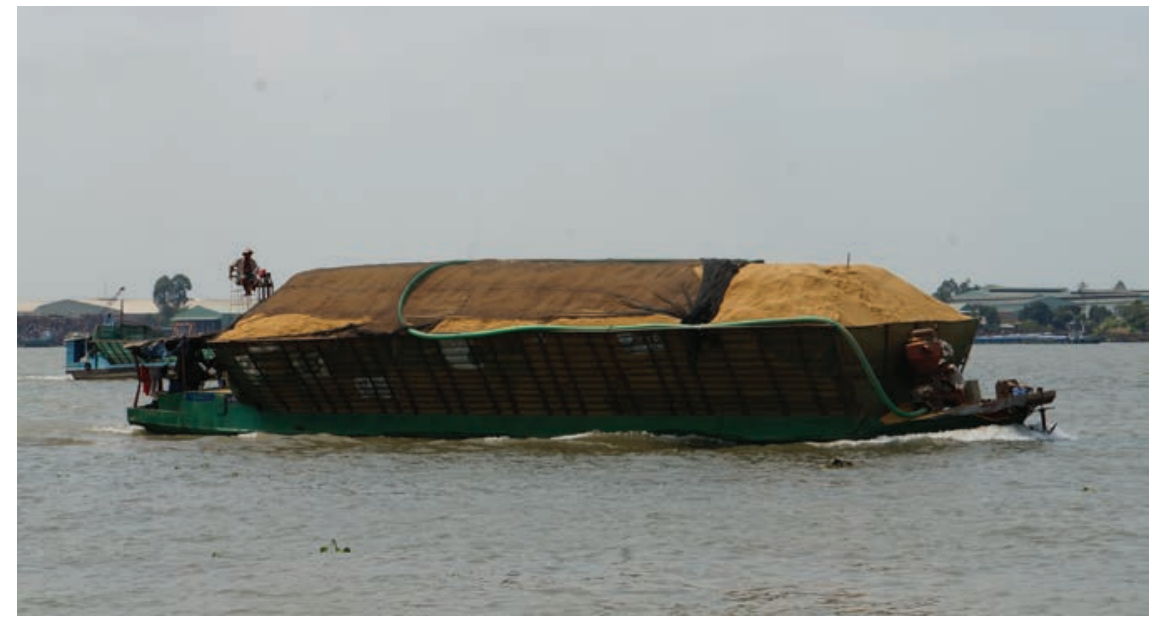

and the ecological services they provide and not solved the saltwater incursions into freshwater systems or acidification of soils (Taylor 2014). Further, high inputs of fertilizers and pesticides required by new rice varieties to assure high yields have leaked into the water-based landscape, resulting in even fresh water that is not safe for drinking. Threats of rising sea levels from a changing climate, reduced water flows on the Mekong from upriver dams (Olson and Morton 2018a), and modifications of the delta wetland hydrology are affecting the creation and replenishment of the river delta.

\section{MEKONG DELTA GEOGRAPHY AND GEOLOGY}

The Mekong Delta, one of the largest deltas in the world, begins near Phnom Penh, Cambodia (figure 1). Formed by the 4,350 $\mathrm{km}$ (2,703 mi) long Mekong River as it flows south and empties through a network of nine channels into the South China Sea, about $35 \%$ of the delta is in Cambodia and $65 \%$ in Vietnam. The Bassac River splits from the Mekong River in the lowlands east of Phnom Penh, and the rivers run parallel to each other to the sea. Multiple channels carry sediments from the upper Mekong River and deposit them throughout the delta, creating midstream sand and silt bars and natural levees that migrate and overtop at high flood stage during the southwest monsoon (Gupta 2009).

\section{Figure 3}

a "flooded" mountain region along the Cambodia-Vietnam border west of the Bassac River (figure 3) and southern coastal dunes, which are high points above the plains and marshlands. The terrain is the result of tectonic uplift and folding by collision of Eurasian and Indian tectonic plates (Gupta 2009). The Mekong River drainage system developed where the underlying geological structure is active and heterogeneous. The elevation of the Tibetan Plateau, where the Mekong River originates, was an important factor in the genesis of the monsoon season, a key climatic influence on the delta hydrology (Asian Development Bank 2012). About 8 million years ago, 76\% of the delta sediments came from the Tibetan Plateau and erosion off the Three Rivers area (Yangtze, Yellow, and Mekong rivers). More recently, up to $51 \%$ of the sediment comes from the Central Highlands (Thailand and Cambodia), and the Three River area contribution dropped to $40 \%$ (Clift et al. 2004).

The last glacial period ended abruptly 19,000 years ago when sea levels rose

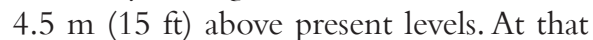
time, the shoreline of the South China Sea almost reached modern day Phnom Penh, Cambodia (figure 1). The present

Rice harvest is underway in the flooded mountain region on the Cambodia-Vietnam border west of the Bassac River. The main highway with guardrail is built on a levee that confines floodwaters to the rice fields of the flat plains during the monsoon season.

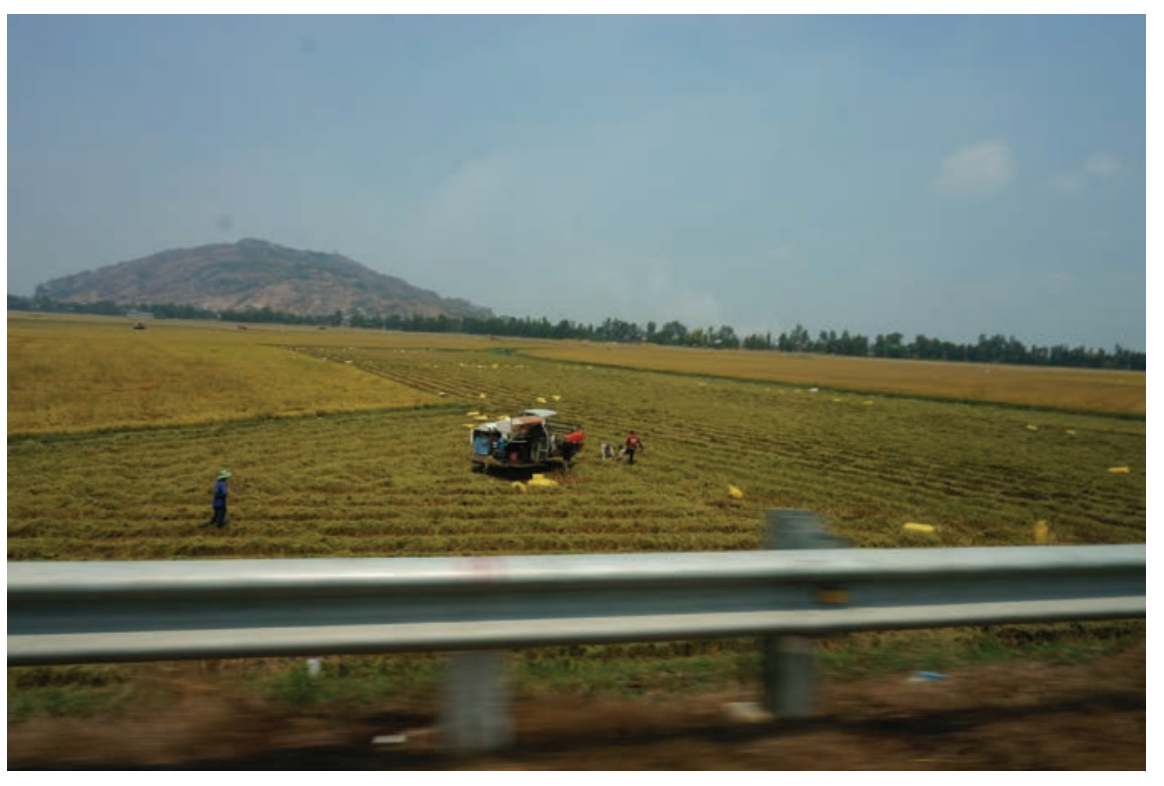


river morphology of the Mekong Delta developed during the last 6,000 to 10,000 years (Mekong River Commission 2010). During this period, the delta advanced 200 $\mathrm{km}(125 \mathrm{mi})$ to the east over the continental shelf of the South China Sea and covered more than $62,000 \mathrm{~km}^{2}(24,000$ $\mathrm{mi}^{2}$ ). The delta was sheltered from wave action and built up through fluvial and tidal process (Carling 2009). Then about $3500 \mathrm{BC}$ the delta advance rate dropped to 17 to $18 \mathrm{~m} \mathrm{y}^{-1}$ (57 to $60 \mathrm{ft} \mathrm{yr}^{-1}$ ) and extended beyond the embayment. This exposed delta deposits to wave action and marine currents that deflected deposition southeast creating $\mathrm{Ca}$ Mau Peninsula, a more recent feature of the Mekong Delta.

The Mekong River has changed course many times, much like the US Mississippi River, due to the low flat topography and unconsolidated parent material. Riverbanks of unconsolidated sediments are unstable and highly erodible. During early geological times the Mekong River discharged into the Red River near current Hanoi, Vietnam. Later it flowed into what is known as the Chao Playa River in Thailand and then into the Gulf of Thailand, south of the modern city of Bangkok (Olson and Morton 2018a, 2018b). During the Holocene, the Mekong River discharged into both the Gulf of Thailand and the South China Sea. A paleo-channel in the western part of the delta, modern day Plain of Reeds and northern Ca Mau Peninsula were once the main drainage system to Gulf of Thailand (Asian Development Bank 2012).

\section{DELTA WETLANDS}

Wetlands are distinct ecosystems where soils are water-saturated permanently or seasonally over prolonged periods from a high water table and/or seasonal flooding (USEPA 2016). Wetland ecosystems have different names (e.g., freshwater marshes, freshwater swamps, bogs and fens, shallow ponds, salt marshes, and mangrove swamps) based on soil characteristics, water sources, and vegetation. The wetlands of the Mekong Delta range from vast seasonally flooded plains with rice paddies and melaleuca forests to shallow freshwater depressions and ponds, backwaters of rivers and streams, brackish salt marshes, mangrove swamps and tidal mudflats along the coasts, and many small offshore islands. The wetland location in the landscape, such as edges of rivers, streams, coastal seas, or low depressions where precipitation and groundwater accumulates, affects the type of plants and animal communities that have adapted to permanent shallow water conditions or fluctuating wet and dry periods. The climate, topography, and hydrology of the Mekong Delta determine when the wetland is fresh water or salt water. Rain and flooding during the wet season flush saltwater canals and rivers and temporally replace salty waterways with fresh water.

Freshwater wetlands are found in Cambodia, the Plain of Reeds in Vietnam, and lands in the central delta between and on both sides of the Bassac and Mekong rivers. Seasonally deposited alluvial soil carried downstream from the Mekong and Bassac rivers is fertile, flooding is moderate in many locations, and the soils (Olson and Morton 2017) in this part of the delta are not saline or acid (Taylor 2014). The central delta is one of the most densely populated areas of the region, with settlements occurring along the river levees where the land is higher and protected from all but the most severe floods. The seasonally inundated wetlands on the backside of the natural levees away from the rivers were intensively drained by canals in the late 1970s and have become major rice growing areas.

Northwest of the central delta is the high floodplain, which seasonally floods over $3 \mathrm{~m}$ (10 ft). About 20 mountain peaks created during the Cretaceous era (part of the Cardamon and Elephant mountains in southwest Cambodia) rise to a height of $700 \mathrm{~m}(2,300 \mathrm{ft}$ ) above the floodplain (figure 3) (Taylor 2014). When the high natural levees of the Mekong and Bassac rivers breach during the wet season, the plains surrounding these mountains can flood up to $5 \mathrm{~m}(16 \mathrm{ft})$ above sea level. Floating rice and other native rice varieties require freshwater wetlands and have historically been well-suited to this seasonal flooding. During the dry season, the water is too acidic for human and animal consumption. The only source of potable water during the dry season is stone-lined wells in the alluvial aprons around the mountains.

The coastal dunes of the delta were formed by waves, currents, and tides of the South China Sea from sand and alluvial sediments of the Mekong River and its various channels. As the delta sediment deposits extended into the sea, the dunes became inland ridges above the coastal wetlands parallel to the coast. Precipitation during the wet season accumulates in depressions and human-made ponds in the dunes and provides the only fresh water in the region. During the five-month dry season, the water evaporates, and the clay soil salts come to the surface, filling the lowlands, salt marshes, and waterways with brackish water (Taylor 2014). Tidal rivers that open to the sea push salt water upstream during high tides and stormy weather, which dilutes and transforms freshwater flows into salty water.

The $250 \mathrm{~km}$ (160 mi) coastline of the Ca Mau Peninsula, the southernmost tip of Vietnam, receives on average $2 \mathrm{~m}$ (78 in) of rain during a wet season that lasts nine months. Home to Nam Can mangrove forests and $\mathrm{U}$ Minh $\mathrm{Ha}$ melaleuca forests, these wetlands protect the coast from erosion and create a 5,200 $\mathrm{km}^{2}\left(2,007 \mathrm{mi}^{2}\right)$ coastal ecosystem with diverse and abundant marine life. Dat Mui Nature Reserve is also in this delta ecosystem. Much of the original mangrove forests were destroyed during the Vietnam War and later converted into fish ponds and agricultural uses. More recently, the fish ponds have been abandoned, and efforts are underway to recolonize inland mangrove forests as well as coastal mudflats. For example, the Bai Boi Protection Forest on the west coast is being recolonized to help protect coastal areas from tropical storms.

Fisheries, aquaculture, agriculture, tourism, roads, and expanding settlements have replaced many of the native coastal wetlands throughout the peninsula. This has increased the region's vulnerability to typhoons, storm surges, coastal erosion, sea level rise from a changing climate, environmental pollution, mangrove logging for shrimp farming and fuel wood, and waste disposal. The Can Tho University Climate Change Research Institute (2009) predicts climate extremes ranging from 
increased flooding in many provinces of the Mekong River during the monsoon season to droughts brought on by dry seasonal decrease in rainfall. Changes in land uses have compromised the capacities of coastal wetlands to sustainably buffer against rising sea levels, filter and store water, and ensure protective ecosystem functions (Asian Development Bank 2012).

\section{CANALS, WATERWAYS, AND THE DUTCH DIKE STRATEGY}

For health, agriculture, commerce, and military reasons, the French made one of the first extensive attempts to partially drain the vast wetlands of the Mekong Delta inVietnam through a series of canals. Historically, this was one of the great mosquito breeding areas of the world, and malaria was common. In addition to drainage efforts, there have been many spray programs to reduce the mosquito populations. During the wet season, local people and visitors risk mosquito-borne malaria, dengue fever, Japanese encephalitis, yellow fever, and Zika. Further, waterborne diseases such as typhoid fever, cholera, diarrhea and vomiting, hepatitis, parasites, and polio in the past and present continue to be major health concerns.

Canals extended waterways and drained the delta wetlands enabling two rice crops a year and planting of high-yield rice varieties. The Dutch dike system consists of dikes (earth embankments) that encircle polders, low-lying wetland areas drained to create agricultural fields with self-contained hydrological systems capable of being connected to networks of ditches or canals by pumps and removable sluices. The sluices and electric or diesel fueled pumps control the water levels within the polder from planting to harvest and manage saltwater incursions into rice fields (Biggs 2011). Post-Vietnam War, this system of wetland farming has grown and provides irrigation during the dry season, creating year-round favorable growing conditions. Dikes, like levees, require constant monitoring and repair, especially when rivers and canals exceed flood stage and water erodes the compacted soil structures. These systems are maintained by local and national government-owned, large-scale water pumping stations and by individually owned small motor pumps multipurposed from farmer-owned speedboats used for marketing agricultural products via the canals and river systems. Total irrigated area in the Mekong Delta is roughly $5 \times 10^{6}$ ha $\left(13 \times 10^{6} \mathrm{ac}\right)$, or over $40 \%$ of the irrigated lands in Vietnam and Cambodia.

Other crops include farmed shrimp and salt along the South China Sea. In both cases, seawater is moved inland and used in shrimp and salt production systems at considerable risk to the groundwater (Ongley 2009). In some places, the groundwater and fresh water have been contaminated with salt, which has leached into the aquifer. In the central delta and along the natural river levees where fresh water is abundant, a diverse range of vegetables and tropical fruits and nuts are grown on high ground (e.g. mangos [Mangifera indica], bananas [Musa paradisium], mandarins and oranges [Citrus sp.], dragon fruit [Hylocereus undatus], and cashews [Anacardium occidentale]).

Many villages and agricultural fields are accessible only by water. Networks of rivers, drainage ditches, and canals are the "roads" of the delta, with all types of boats transporting people; plants; fertil- izer and chemical inputs; animals; and household and agricultural products to and from markets (figure 4). Main roads for cars, motorcycles, and trucks are built on coastal ridges, canal banks, and natural river levees that are continuously heightened with alluvial clays from river bottoms. Highway traffic in small towns and cities is 50 motorcycles to every car or truck. However, cars control the roads in a precarious dance of horn beeping, headlights flashing, hand gestures, alternate acceleration-de-acceleration, and screeching brakes to make motorcycles and pedestrians move over.

\section{INTEGRATED AQUACULTURE AND AGRICULTURE}

Aquaculture in the lower Mekong Delta involves the entire range of fish production from the sale of fry or fingerlings, raising of fry, and rearing wild caught young fish to adults. Freshwater ponds, rice fields, and caged or fenced-off areas in rivers and canals are used in capture fisheries. Brackish-water aquaculture is practiced along the coast in Vietnam Delta ponds and tidal flats. High value fish are sold, low-value fish are eaten by fishers' house-

\section{Figure 4}

Farm to market: cabbages, melons, onions, and other fruits and vegetables are shipped by speedboats from agricultural and horticultural fields to waterside docks. Produce is then transferred to distributors who load them on motorcycles for transport to local stores and street vendors.

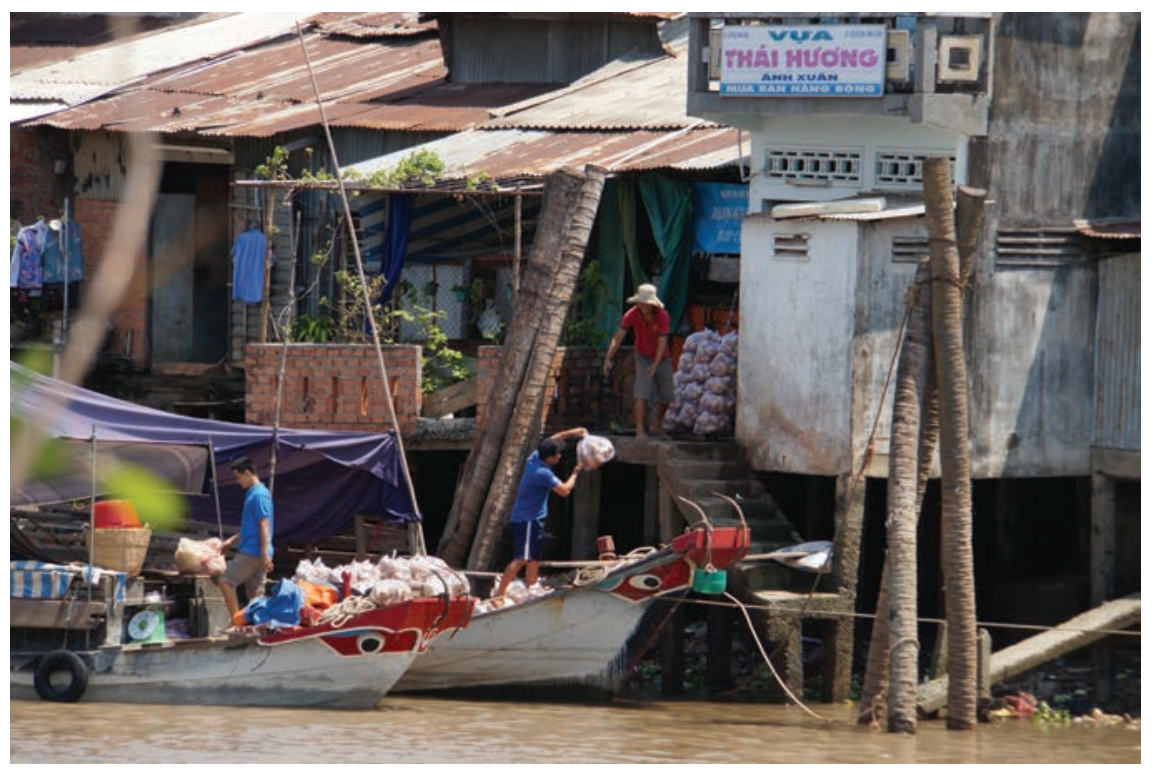


holds, and trash fish are fed to other fish. Aquaculture requires land, equipment, and more capital and labor than capture fisheries along the rivers and coastal waters. The flat terrain of the delta and yearround availability of water from the canal network have resulted in intensification of aquaculture systems. Systems that integrate agriculture and aquaculture are promoted as complementary-minimizing nutrient losses from crops and livestock by concentrating wastes and manures in ponds or trenches where fish are raised and nutrient waste sludge recycled when periodically removed and applied to fruit trees and vegetable crops.

However, large commercial systems usually focus only on aquaculture and seldom recycle the nutrients but tend to release their nutrient enriched water into nearby canals or rivers, thereby polluting downstream waterbodies. Small-scale aquaculture typically produces $<1 \mathrm{t} \mathrm{ha}^{-1} \mathrm{y}^{-1}\left(<0.4 \mathrm{tn} \mathrm{ac}^{-1}\right.$ $\mathrm{yr}^{-1}$ ) shrimp and fish, while intensive systems for shrimp can produce up to $9 \mathrm{tha}^{-1}$ $\mathrm{y}^{-1}\left(4.0\right.$ tn $\left.\mathrm{ac}^{-1} \mathrm{yr}^{-1}\right)$ and catfish culture can produce up to $1,000 \mathrm{t} \mathrm{ha}^{-1} \mathrm{y}^{-1}$ (446 tn $\mathrm{ac}^{-1}$ $\left.\mathrm{yr}^{-1}\right)$. The estimated aquaculture production in fresh water has grown from 60,000 t ha $\mathrm{y}^{-1}\left(26,800 \mathrm{tn} \mathrm{ac}^{-1} \mathrm{yr}^{-1}\right)$ in 1990 to $260,000 \mathrm{t} \mathrm{ha}^{-1} \mathrm{y}^{-1}\left(116,000 \mathrm{tn} \mathrm{ac}^{-1} \mathrm{yr}^{-1}\right)$ in 2000 (Phillips 2002). High value shrimp produced in fresh water and brackish water increased to $135,000 \mathrm{tha}^{-1}\left(60,200 \mathrm{tn} \mathrm{ac}^{-1}\right.$ $\left.\mathrm{yr}^{-1}\right)$ from 72,000 $\mathrm{t} \mathrm{ha}^{-1} \mathrm{y}^{-1}\left(31,100 \mathrm{tn} \mathrm{ac}^{-1}\right.$ $\left.\mathrm{yr}^{-1}\right)$. In the Vietnam Delta, $14 \%$ to $61 \%$ of households are engaged in aquaculture depending on the region (Hortle 2007).

\section{CRICKET FARMING AND INSECT PRODUCTION}

High rainfall, humidity, and the alternating wet and dry tropical climate of the Mekong Delta create ideal conditions for fast reproduction of many types of insects. Although insects can harm agricultural crops and carry diseases, the farmers of the region have innovatively turned this abundance into a profitable market for high quality protein (figure 5). Many Cambodian children have a protein deficiency, and parents have taken up cricket farming as a cheaper source of protein than fish. Cricket waste can then be used as a fertilizer.

\section{Figure 5}

Bowls of ready-to-eat crickets, tarantulas, cicadas, grasshoppers, insect larvae, and beetles are garnished with scallions and hot red peppers and sold at a roadside stand in the Mekong Delta of Cambodia.

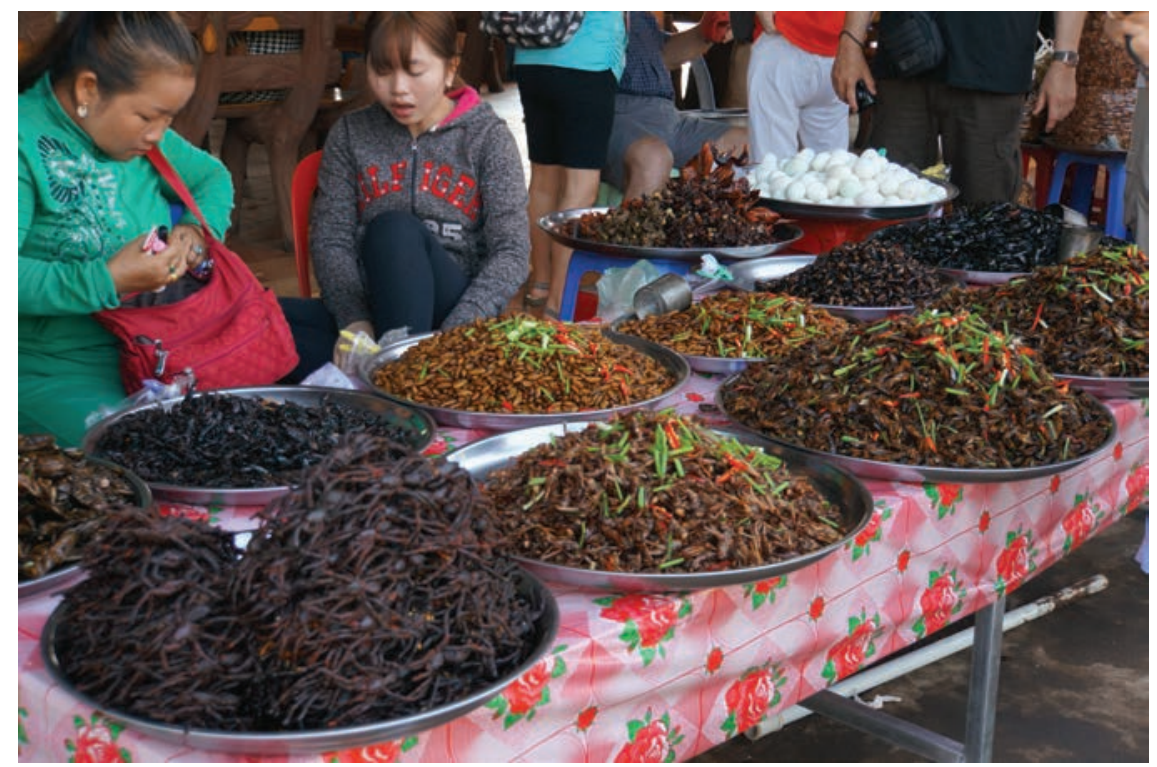

\section{MEKONG RIVER NAVIGATION AND DAMS}

The delta coastal region and the Mekong River and distributaries for thousands of years have fostered local and international commerce and trade. Today the upper Mekong River in China is controlled by a series of dams and reservoirs that have altered navigation patterns and the flow of water and sediment to the Mekong Delta. Further south, Laos is constructing a hydroelectric dam and planning more (Olson and Morton 2018a).

Sediment and associated nutrients shape the morphology of the Mekong Delta (Walling 2009) and influence livelihoods dependent on fisheries and annually flooded rice fields. Data on sediment flows are limited, but it has been estimated that the total sediment load is as much as 1.11

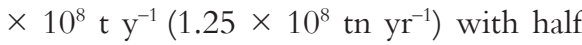
coming from the Lancang catchment in China. However, the creation of dams and huge reservoirs on the main Mekong stem seems to reduce the sediment delivery to the delta. Since 1994, up to 12 main stem dams have been proposed on the lower Mekong River in Laos and Cambodia. Xayaburi, the first of these to be submitted to the Mekong River Commission, is a proposed $32 \mathrm{~m}$ (100 ft) high, 1,260
MW dam located $150 \mathrm{~km}$ (95 mi) downstream from Luang Prabang. Member countries concerned about changes in the river pulse and downriver effects on sediment distribution and water quality have requested additional environmental and human impact studies be undertaken.

Navigation upriver from the South China Sea is blocked by Khone Falls just above Kratie near the Cambodia-Laos border (figure 1). Many barges loaded with military ordnances during the 1970s Indochina wars were sunk in Cambodian sections of the Mekong River. These unexploded ordnances created huge problems for future bridge construction, navigation, irrigation systems, and local fishers. By 2013 Cambodian volunteers were trained with support from the Office of Weapons Removal and Abatement, US State Department, Bureau of Political-Military Affairs to conduct underwater explosive removal (Escalante 2007). Container traffic at Phnom Penh port and general cargo through Can Tho port (Vietnam) increased steadily until the global financial crises of 2009. However, the construction of a new deepwater port at Cai Mep in Vietnam allows ships with $15.2 \mathrm{~m}$ (50 ft) draft to be loaded. Now Cai Mep can handle the largest container ships 
in world, and these ships travel directly to Europe and the United States carrying raw and finished products from Southeast Asia.

\section{CONCLUSIONS}

Local communities in the Mekong Delta are highly dependent on fish for food security (Ferguson et al. 2012), aquaculture and rice production (figure 6) for household livelihoods, and availability of safe drinking water (Morton and Olson 2018). Mekong Delta agricultural production has more than doubled in the last twenty years, with related growth in demand for water quantity and quality. Rapid modernization of delta agriculture has increased fertilizer and pesticide inputs used to achieve high rice yields. It has also increased debt loads of subsistence farmers newly dependent upon contract farming and the ups and downs of market economies (Santasombat 2011). Agricultural use accounts for 95\% of the water use within the delta. Rainfed agriculture dominates the delta, but approximately $31 \%$ of Vietnam and $15 \%$ of Cambodia is irrigated agriculture. These percentages are expected to increase as agricultural production intensifies and the population continues to grow.

Large-scale fishing and aquaculture have expanded rapidly in the Cambodia Tonle Sap Lake and River region (Olson and Morton 2018b) and the Mekong Delta. Almost $2.6 \times 10^{6}$ ha $\left(7 \times 10^{6} \mathrm{ac}\right)$ of the Mekong Delta is in agriculture and represents $25 \%$ of Vietnam's total agricultural land. The Vietnam Delta rice output in 2011 was $2.07 \times 10^{8} \mathrm{t}\left(2.32 \times 10^{8}\right.$ $\mathrm{tn})$, or $54 \%$ of all Vietnam rice production (General Statistics Office 2011). The Mekong Delta is also an important fishing region with an output of $2.829 \times 10^{6} \mathrm{t} \mathrm{y}^{-1}$

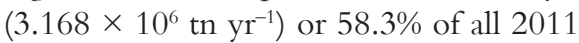
Vietnam fish production.

Loss of wetland ecologies is a concern, and water conditions are routinely monitored for the entire Mekong River, including the delta region. Status reports are issued annually by the Mekong River Commission. Although pollution from agricultural, industrial, and urban sources cause elevated nutrient levels near urban centers and in some tributaries draining agricultural lands, impacts are localized, and nutrient concentrations usually remain within acceptable levels. Due to organic matter discharges from urban areas and runoff from forests, agriculture, industry, and aquaculture, chemical oxygen $\left(\mathrm{O}_{2}\right)$ demand increases with distance downriver.

More than $1,600 \mathrm{~km} \quad(1,000 \mathrm{mi})$ downriver from the Chinese dams, the Mekong's Delta network of wetlands and waterways empties into the South China Sea. Centuries of human efforts to manage the river and delta have resulted in a complex engineered landscape. Wetland restoration has been a recent priority, but current and future dams in China and proposed dams in Laos and Cambodia on the upper Mekong River may compromise these efforts. The balance between the South China Sea and the river is already shifting. Recent droughts like that of the spring of 2016 have weakened the river's freshwater flows and allowed seawater to intrude farther upriver causing serious problems for farmers.

The Lancang (Mekong) River in China has an annual runoff of $74 \mathrm{~km}^{3}\left(18 \mathrm{mi}^{3}\right)$ and contributes $14 \%$ to $16 \%$ of the average total annual flow of the Mekong River of $460 \mathrm{~km}^{3}\left(110 \mathrm{mi}^{3}\right)$ at its mouth but $30 \%$ of the dry season flow (General Statistics Office 2011). If all the proposed dams are

\section{Figure 6}

Rice shelling and cleaning mills are located along Mekong River banks. Empty fertilizer bags are repurposed by filling with cleaned rice that are loaded onto boats for transport to market.

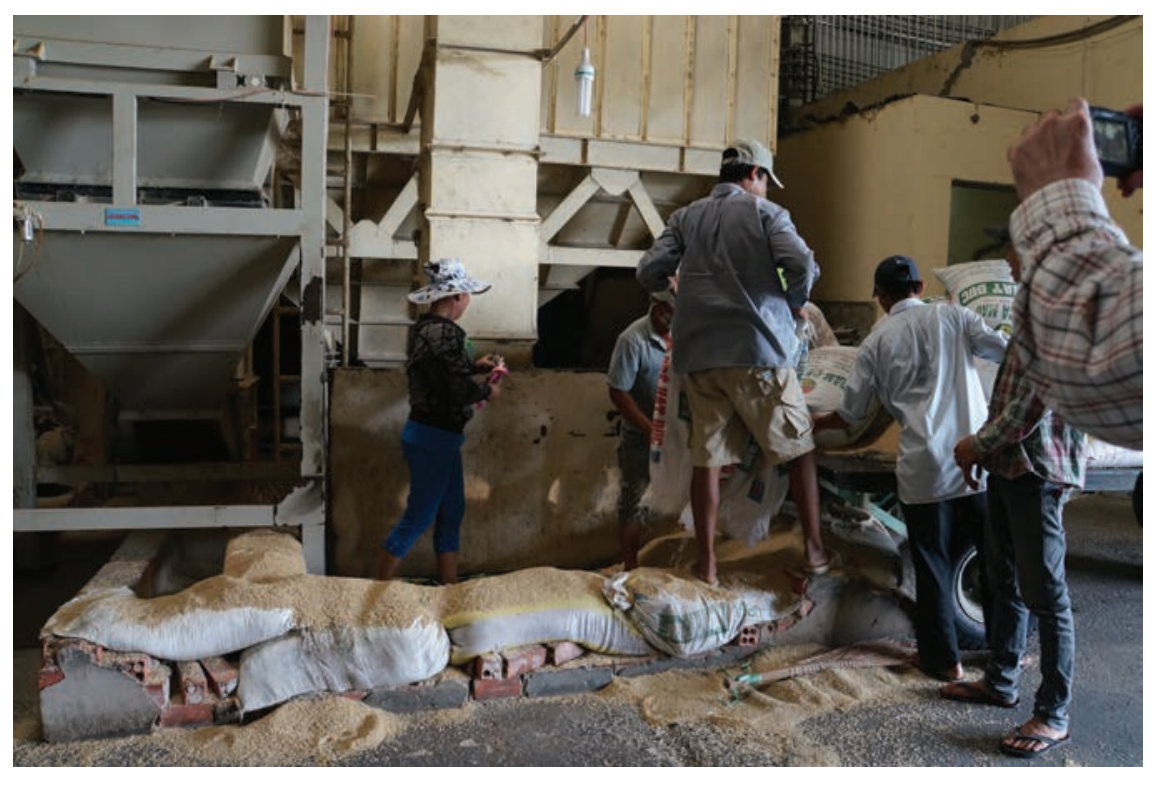

built, more than half of the lower Mekong River water could be captured in reservoirs, and the seasonal flow of the river considerably altered (Olson and Morton 2018a). Further, these reservoirs will trap much of the nutrient-rich sediment that now fertilizes delta fields and feeds fish throughout the entire Mekong River and Delta system. The rich sediment deposited in the delta during the monsoon season is important to agricultural production, and even the fishing grounds in the South China Sea will be less productive without sufficient sediment. The Vietnamese boats that fish in the productive plume of the South China Sea catch more than 446,000 t y ${ }^{-1}(500,000 \mathrm{tn}$ $\mathrm{yr}^{-1}$ ) each year (Ferguson 2012).

The Mekong River is not alone in these environmental challenges. The deltas of the Mississippi, the Yangtze, the Nile, and the Red River of Vietnam are also experiencing loss of wetlands, flood disasters, poor water quality, reduced soil capacity to filter and absorb excess agricultural nutrients and other pollutants, and the need to increase food production for expanding populations (Biggs 2011). Historical perspectives, new science and technologies, and public and political efforts are critical if the deltas of the present and future 
are to ensure an environment habitable for human well-being and strong agricultural productivity while strategically conserving wetland ecologies.

\section{ACKNOWLEDGEMENT}

Published with funding support from the Director of the Illinois Office of Research, College of Agricultural, Consumer, and Environmental Science, University of Illinois, Urbana, Illinois, and the Iowa Agriculture and Home Economics Experiment Station, College of Agriculture and Life Sciences at Iowa State University, Ames, Iowa.

\section{REFERENCES}

Asian Development Bank. 2012. Greater Mekong Subregion Atlas of the Environment. Metro Manila, Philippines: Asian Development Bank.

Biggs, D. 2011. Fixing the Delta: History and the politics of hydraulic infrastructure development and conservation in the Mekong Delta. In Environmental Change and Agricultural Sustainability in the Mekong Delta, eds. M.A. Steward and P.A. Coclanis, 35-44. New York: Springer.

Carling, P.A. 2009. Geomorphology and sedimentology of the lower Mekong River. In The Mekong: Biophysical Environment of an International River Basin, ed. I.C. Campbell, 77-111. New York: Elsevier.

Clift, P.D., G.D. Layne, and J. Blusztajn. 2004. Marine sedimentary evidence for monsoon strengthening, Tibetan uplift and drainage evolution in East Asia. Geophysical Monograph Series 149:255-282.

Climate Change Research Institute. 2009. Mekong Delta more food and drought Vietnam. Net bridge.Vietnam: The Can Tho University.

Escalante, Y.R. 2007. Weapons removal and abatement and humanitarian mine action. Office of Weapons Removal and Abatement. Washington, DC: Bureau of Political-Military Affairs, US State Department.

Ferguson, J.W., M. Healy, P. Dugan, and C. Barlow. 2012. Potential effects of dams on migratory fish in Mekong River: Lessons from the Frazer and Columbia rivers. Environmental Management 47(1):141-159.

General Statistics Office. 2011. Statistics Yearbook of Vietnam.Vietnam: Statistical Publishing House.

Gupta, A. 2009. Geology and landforms of the Mekong Basin. In The Mekong: Biophysical Environment of an International River Basin, ed. I.C. Campbell, 251-272. New York: Elsevier.

Hortle, K.G. 2007. Consumption and the yield of fish and other aquatic animals from the Lower
Mekong Basin. Mekong River Commission Technical Paper 16.Vientiane, Lao PDR: Mekong River Commission.

Mekong River Commission. 2010. The first Mekong River Commission Summit, 4-5 April 2010.

Morton, L.W., and K. R. Olson. 2018. The pulses of the Mekong River basin: Rivers and the livelihoods of farmers and fishers. Journal of Environmental Protection 9(4):431-459, doi:10.4236/jep.2018.94027.

Olson, K.R., and L.W. Morton. 2016. Managing Mississippi and Ohio River Landscapes. Ankeny, IA: Soil and Water Conservation Society. http:// www.swcs.org/en/publications/managing_mississippi_and_ohio_river_landscapes/.

Olson, K.R., and L.W. Morton. 2017. Why were the soil tunnels of $\mathrm{Cu} \mathrm{Chi}$ and Iron Triangle in Vietnam so resilient? Open Journal of Soil Science 7:34-51, doi:10.4236/ojss.2017.72003.

Olson, K.R., and L.W. Morton 2018a. Water rights and fights: Lao dams on the Mekong River. Journal of Soil and Water Conservation 73(2):35A-41A, doi:10.2489/jswc.73.2.35A.

Olson, K.R., and L.W. Morton. 2018b. Tonle Sap Lake and River and confluence with Mekong River in Cambodia. Journal of Soil and Water Conservation 73(3):60A-66A, doi:10.2489/ jswc.73.3.60A.

Ongley, E.D. 2009. Water Quality of the Lower Mekong River. In The Mekong: Biophysical Environment of an International River Basin, ed. I.C. Campbell, 297-320. New York: Elsevier.

Phillips, M.J. 2002. Freshwater aquaculture in Lower Mekong Basin. Mekong River Commission Techhnical Paper 7:62.

Santasombat, Y. 2008. Flexible Peasants: Re-conceptualizing the Third World's Rural Types. Thailand: Chiang Mai University, Regional Center for Social Science and Sustainable Development.

Taylor, P. 2014. The Khmer Lands of Vietnam. Environment, Cosmology and Sovereignty. Asian Studies Association of Australia: Southeast Asia Publications. Honolulu: University of Hawaii Press. USEPA (US Environmental Protection Agency). 2016. National Wetland Condition Assessment 2011: A Collaborative Survey of the Nation's Wetlands. EPA 843 R 15 005. https://www.epa. gov/sites/production/files/2016-05/documents/ nwca_2011_public_report_20160510.pdf.

Walling, D.E. 2009.The sediment load of the Mekong River. Geomorphology and sedimentology of the Lower Mekong River. In The Mekong: Biophysical Environment of an International River Basin, ed. I.C. Campbell, 113-142. New York: Elsevier. 